\title{
PENINGKATAN KETERAMPILAN MENYIMAK DONGENG DENGAN PENDEKATAN INTEGRATIF MELALUI TEKNIK DENGAR-CERITA SISWA KELAS II SD NEGERI 200106 PADANGSIDIMPUAN TAHUN PELAJARAN 2015-2016
}

\author{
FAUSIAH, S.Pd. \\ NIP: 196202071983042004 \\ Email : fausiah879@gmail.com
}

\begin{abstract}
abstrak
Berdasarkan observasi awal yang dilakukan penulis, keterampilan menyimak dongeng kelas II SD Negeri 200106 Padangsidimpuan masih rendah. Rendahnya kemampuan siswa dalam menyimak dongeng disebabkan oleh (1) siswa kurang memahami keterampilan menyimak, (2) manfaat yang didapat dari menyimak dongeng dirasakan kurang oleh siswa, sehingga menyebabkan siswa kurang antusias, (3) teknik pembelajaran menyimak dongeng kurang bervariasi, (4) pendekatan yang digunakan guru belum tepat. Pemilihan pendekatan dan teknik berdasarkan tuntutan KBK memberi kebebasan kepada guru untuk memilih pendekatan dan teknik yang beragam dan sesuai dengan tujuan pembelajaran.
\end{abstract}

Berdasarkan paparan di atas, penelitian ini mengkaji dua masalah yaitu (1) bagaimanakah peningkatan keterampilan menyimak dongeng dengan pendekatan integratif melalui teknik dengarcerita pada siswa kelas II SD Negeri 200106 Padangsidimpuan setelah mengikuti pembelajaran dan (2) bagaimanakah perubahan perilaku siswa setelah dilakukan pembelajaran keterampilan menyimak dongeng dengan pendekatan integratif melalui teknik dengar-cerita pada siswa kelas II SD Negeri 200106 Padangsidimpuan setelah mengikuti pembelajaran.

Penelitian ini dilaksanakan dalam dua tahap, yaitu tahap pratindakan dan tindakan. Tahap tindakan terdiri atas siklus I dan siklus II. Subjek penelitian ini adalah keterampilan menyimak dongeng kelas II SD Negeri 200106 Padangsidimpuan. Penelitian ini menggunakan dua variabel, yaitu peningkatan keterampilan menyimak dongeng dan pendekatan integratif melalui teknik dengarcerita. Pengumpulan data pada penelitian ini menggunakan teknik tes dan nontes. Teknik tes berupa hasil menceritakan isi dongeng. Untuk tes nontes berupa data perilaku siswa dari hasil observasi, jurnal siswa, jurnal guru, wawancara, dan dokumentasi kepada siswa. Teknik analisis data kualitatif menggunakan deskripsi kuantitatif. Kedua teknik tersebut dianalisis dengan membandingkan hasil tes siklus I dan siklus II.

Hasil penelitian ini menunjukkan adanya peningkatan keterampilan menyimak dongeng dengan teknik dengar-cerita melalui pendekatan integratif. Nilai rata-rata kelas pada tahap pratindakan sebesar 67,10 dan mengalami peningkatan sebesar 2,9\% menjadi sebesar 70 . Selanjutnya pada siklus II nilai rata-rata kelas meningkat menjadi 84,3. Setelah menggunakan pendekatan integratif melalui teknik dengar-cerita juga terjadi perubahan tingkah laku siswa. Siswa yang sebelumnya merasa kurang antusias terhadap pembelajaran menyimak dongeng menjadi antusias, senang, dan tertarik setelah mengikuti pembelajaran keterampilan menyimak dongeng dengan pendekatan integratif melalui teknik dengar-cerita.

Kata Kunci : Keterampilan menyimak, pendekatan integratif. 


\section{PENDAHULUAN}

Dalam era pembangunan dewasa ini makin lama makin kita rasakan pentingnya berkomunikasi baik antar anggota masyarakat maupun antar kelompok masyarakat.Alat komunikasi yang ampuh adalah bahasa. Dengan bahasa, manusia sebagai makhluk sosial dapat berhubungan satu sama lain secara efektif dan dapat menyatakan perasaan, pendapat bahkan dengan bahasa kita dapat berpikir dan bernalar. Bahasa juga memungkinkan manusia untuk saling berhubungan, saling berbagi pengalaman, saling belajar dari yang lain, dan "untuk meningkatkan kemampuan intelektual dan kesusasteraan merupakan salah satu sarana untuk menuju pemahaman tersebut" (Depdiknas 2004: 2). Oleh sebab itu, agar komunikasi berjalan dengan lancar, kita perlu terampil berbahasa baik lisan maupun tulis.Suatu komunikasi dikatakan berhasil apabila pesan yang disampaikan dapat dipahami dengan baik oleh penyimak suatu makna atau maksud.

\section{Menurut (Tarigan), keterampilan} berbahasa (atau language arts, language skills) dalam kurikulum mencakup empat jenis, yaitu "keterampilan menyimak (listening skills), keterampilan berbicara (speaking skills), keterampilan membaca (reading skills) dan keterampilan menulis (writing skills).(Tarigan, 1994: 2).Keterampilan menyimak merupakan salah satu keterampilan pertama yang dipelajari oleh manusia, kemudian berbicara diikuti dengan membaca dan menulis.Keempat keterampilan tersebut merupakan catur tunggal, yaitu antara satu dengan lainnya saling berhubungan dan satu kesatuan yang tidak dapat dipisahkan.

Setiap keterampilan itu erat pula berhubungan dengan proses-proses berpikir yang mendasari bahasa.Bahasa seseorang mencerminkan pikirannya.Seseorang yang terampil berbahasa maka jalan pikirannya semakin cerah dan jelas."Keterampilan hanya dapat diperoleh dan dikuasai dengan jalan praktik dan banyak latihan. Melatih keterampilan berbahasa itu pula melatih keterampilan berpikir" (Dawson, dalam Tarigan 1985b: 1)

Mata pelajaran bahasa Indonesia berdasarkan kurikulum berbasis kompetensi adalah program untuk mengembangkan pengetahuan, keterampilan berbahasa, dan sikap positif terhadap bahasa Indonesia. Menyimak merupakan salah satu bagian dari mata pelajaran Bahasa dan Sastra Indonesia dalam kurikulum berbasis kompetensi.Kurikulum berbasis kompetensi meliputi aspek kemampuan berbahasa dan aspek kemampuan bersastra. Aspek keterampilan berbahasa meliputi keterampilan mendengarkan, berbicara, membaca dan menulis yang berhubungan dengan ragam sastra.Dalam pembelajaran bahasa dan sastra Indonesia, aspek keterampilan berbahasa dan keterampilan bersastra harus dilakukan secara seimbang.

Menyimak merupakan salah satu faktor penting yang dipergunakan waktu proses belajar mengajar dalam kelas. Hal itu dikarenakan siswa harus bisa menyimak penjelasan guru dengan baik. Jika siswa tidak bisa menyimak dengan baik secara otomatis apa yang disampaikan guru tidak berhasil. Jadi, keberhasilan siswa dalam pelajaran ditentukan oleh baik buruknya siswa dalam hal menyimak.Berdasarkan hal-hal tersebut maka menyimak perlu dikuasai dan ditingkatkan dengan baik.

Pada kenyataannya pembelajaran menyimak kurang diperhatikan dengan baik dan sering kali diremehkan oleh siswa.Hal itu menyebabkan siswa kurang maksimal dalam pembelajaran menyimak. Oleh sebab itu, guru harus bisa memilih cara agar dalam pembelajaran berhasil.

Pembelajaran dengan pendekatan integratif dapat dijadikan sebagai strategi untuk meningkatkan keterampilan menyimak dongeng siswa. Integratif merupakan konsep belajar yang menyatukan beberapa aspek ke dalam satu proses. Integratif dibagi menjadi dua yaitu interbidang studi dan antarbidang studi.Interbidang studi artinya beberapa aspek dalam satu bidang studi ini diintegrasikan.

Pembelajaran dengan pendekatan integratif dan teknik dengar-cerita diharapkan dapat meningkatkan keterampilan menyimak dongeng siswa kelas II SD Negeri 200106 Padangsidimpuan. Dalam pembelajaran tersebut kegiatan belajar diaplikasikan sesuai dengan kompetensi dasar yang dimiliki siswa.Materi tidak dipisah-pisahkan, sehingga menggunakan pendekatan integratif.Jadi meskipun keterampilan yang digunakan adalah menyimak maka dipadukan dengan keterampilan berbicara. 
Volume 3 Nomor 1, Halaman 1-81, Januari--Juni 2018

RISTEKDIK | Jurnal Bimbingan dan Konseling

P-ISSN: 2527-4244, E-ISSN : 2541-206X

Dengan cara tersebut diharapkan dapat mengatasi Tabel 15. Nilai Komulatif Menyimak Dongeng kesulitan belajar siswa.

\section{Metode Penelitian}

Sebagai metode penelitian yang digunakan adalah metode penelitian tindakan kelas (PTK) dengan desain sebagai berikut :

Penelitian ini peneliti menggunakan penelitian tindakan kelas (PTK) yang merupakan bentuk kajian yang sistematis reflektif oleh pelaku tindakan yang dilakukan untuk meningkatkan kemantapan rasional dari tindakan mereka dalam melaksanakan tugas, memperdalam pemahaman terhadap tindakantindakan yang dilakukannya itu, serta memperbaiki kondisi pembelajaran (Depdiknas 2004: 7).

Penelitian tindakan kelas bersifat reflektif artinya dalam proses penelitian, guru sekaligus sebagai peneliti yang memikirkan apa dan mengapa suatu tindakan terjadi di kelas, dari pemikiran itu kemudian guru mencari pemecahannya melalui tindakan-tindakan tertentu (Suyatno dalam Depdiknas 2004: 7).

Penelitian tindakan kelas ini dilaksanakan dalam bentuk siklus yang terdiri 413/33=12,57 dan termasuk dalam kategori atas empat tahap, yakni perencanaan, tindakan, cukup. observasi, dan refleksi.

\section{HASIL PENELITIAN DAN PEMBAHASAN} Hasil Siklus I

Tabel 14. Skor Komulatif Menyimak Dongeng Siklus I

\begin{tabular}{|c|c|c|c|c|c|c|}
\hline No & Kategori & $\begin{array}{l}\text { Rentang } \\
\text { Skor }\end{array}$ & Frekuensi & $\begin{array}{l}\text { Bobot } \\
\text { Skor }\end{array}$ & $\%$ & Rata-rata \\
\hline 1. & $\begin{array}{l}\text { Sangat } \\
\text { Baik }\end{array}$ & $68-80$ & 7 & 512 & 21.21 & \multirow{5}{*}{\begin{tabular}{|l}
$1947 /$ \\
$33=5$ \\
9 \\
berka \\
tegori \\
baik
\end{tabular}} \\
\hline 2. & Baik & $56-67$ & 13 & 825 & 39.39 & \\
\hline 3. & Cukup & $44-55$ & 9 & 442 & 27.27 & \\
\hline 4. & Kurang & $0-43$ & 4 & 168 & 12.12 & \\
\hline \multicolumn{2}{|c|}{ Jumlah } & & 33 & 1947 & 100 & \\
\hline
\end{tabular}

Rata-rata skor komulatif yaitu 1947:33=59. Hal tersebut menunjukkan bahwa pada skor komulatif menyimak dongeng secara klasikal berkategori cukup. Tabel 17. Hasil Tes Aspek Tokoh dan

Perwatakan Siklus I

\begin{tabular}{|c|c|c|c|c|c|c|}
\hline No & $\begin{array}{l}\text { Katego } \\
\text { ri }\end{array}$ & $\begin{array}{l}\text { Rentang } \\
\text { Skor }\end{array}$ & Frekuensi & $\begin{array}{l}\text { Bobot } \\
\text { Skor }\end{array}$ & $\%$ & $\begin{array}{l}\text { Rata- } \\
\text { rata }\end{array}$ \\
\hline 1. & $\begin{array}{l}\text { Sangat } \\
\text { Baik }\end{array}$ & $16-20$ & 7 & 130 & 21.21 & $\begin{array}{l}414 / 3 \\
3=12,\end{array}$ \\
\hline 2. & Baik & $11-15$ & 11 & 152 & 33.33 & \\
\hline 3. & Cukup & $6-10$ & 13 & 124 & 39.39 & $\begin{array}{l}\text { berka } \\
\text { tegori }\end{array}$ \\
\hline 4. & Kurang & $0-5$ & 2 & 8 & 6.06 & cukup \\
\hline \multicolumn{2}{|c|}{ Jumlah } & & 33 & 414 & 100 & \\
\hline
\end{tabular}

Nilai rata-rata kelas dalam aspek ini adalah $414 / 33=12,55$ dan termasuk dalam kategori cukup.

\begin{tabular}{|c|c|c|c|c|c|c|}
\hline No & Kategori & $\begin{array}{l}\text { Rentang } \\
\text { Nilai }\end{array}$ & Frekuensi & $\begin{array}{l}\text { Bobot } \\
\text { Nilai }\end{array}$ & $\%$ & $\begin{array}{l}\text { Rata- } \\
\text { rata }\end{array}$ \\
\hline 1. & $\begin{array}{l}\text { Sangat } \\
\text { Baik }\end{array}$ & $85-100$ & 6 & 580 & 18.18 & $\begin{array}{l}23 \\
15 /\end{array}$ \\
\hline 2. & Baik & $70-84$ & 11 & 833 & 33.33 & 33 \\
\hline 3. & Cukup & $55-69$ & 12 & 710 & 36.36 & $=7$ \\
\hline 4. & Kurang & $0-54$ & 4 & 192 & 12.12 & ber \\
\hline \multicolumn{3}{|c|}{ Jumlah } & 33 & 2315 & 100 & kat \\
\hline
\end{tabular}

Rata-rata skor komulatif yaitu 2315:33=70. Hal ersebut menunjukkan bahwa pada nilai komulatif menyimak dongeng secara klasikal Tabel 16. Hasil Tes Aspek Kesesuaian Isi Dongeng Siklus I

\begin{tabular}{|c|c|c|c|c|c|c|}
\hline No & Kategori & $\begin{array}{l}\text { Rentang } \\
\text { Skor }\end{array}$ & Frekuensi & $\begin{array}{l}\text { Bobot } \\
\text { Skor }\end{array}$ & $\%$ & $\begin{array}{l}\text { Rata- } \\
\text { rata }\end{array}$ \\
\hline 1. & $\begin{array}{l}\text { Sangat } \\
\text { Baik }\end{array}$ & $16-20$ & 10 & 171 & 30.30 & $\begin{array}{l}413 / 3 \\
3=12\end{array}$ \\
\hline 2. & Baik & $11-15$ & 9 & 120 & 27.27 & 57 \\
\hline 3. & Cukup & $6-10$ & 14 & 122 & 42.42 & $\begin{array}{l}\text { berkate } \\
\text { gori }\end{array}$ \\
\hline 4. & Kurang & $0-5$ & 0 & 0 & 0 & cukup \\
\hline \multicolumn{3}{|c|}{ Jumlah } & 33 & 413 & 100 & \\
\hline
\end{tabular}

Nilai rata-rata kelas pada aspek ini adalah cukup. 
Volume 3 Nomor 1, Halaman 1-81, Januari--Juni 2018

RISTEKDIK | Jurnal Bimbingan dan Konseling

P-ISSN: 2527-4244, E-ISSN : 2541-206X

4

Tabel 18. Hasil Tes Aspek Latar Siklus I

\begin{tabular}{|c|c|c|c|c|c|c|}
\hline No & Kategori & $\begin{array}{l}\text { Rentang } \\
\text { Skor }\end{array}$ & Frekuensi & $\begin{array}{l}\text { Bobot } \\
\text { Skor }\end{array}$ & $\%$ & $\begin{array}{l}\text { Rata- } \\
\text { rata }\end{array}$ \\
\hline 1. & $\begin{array}{l}\text { Sangat } \\
\text { Baik }\end{array}$ & $9-10$ & 17 & 165 & 51.52 & \multirow{5}{*}{$\begin{array}{l}275 / 3 \\
3=8,3 \\
\text { berkate } \\
\text { gori } \\
\text { baik }\end{array}$} \\
\hline 2. & Baik & $7-8$ & 12 & 89 & 36.36 & \\
\hline 3. & Cukup & $4-6$ & 4 & 21 & 12.12 & \\
\hline 4. & Kurang & $0-3$ & 0 & 0 & 0 & \\
\hline \multicolumn{3}{|c|}{ Jumlah } & 33 & 275 & 100 & \\
\hline
\end{tabular}

Rata-rata kelas dalam hasil tes menyimak dongeng aspek latar adalah sebesar 275/33=8,3 dan termasuk dalam kategori baik.

Tabel 19. Hasil Tes Aspek Mimik Siklus I

\begin{tabular}{|c|c|c|c|c|c|c|}
\hline No & $\begin{array}{l}\text { Katego } \\
\text { ri }\end{array}$ & $\begin{array}{l}\text { Rentang } \\
\text { Skor }\end{array}$ & Frekuensi & $\begin{array}{l}\text { Bobot } \\
\text { Skor }\end{array}$ & $\%$ & $\begin{array}{l}\text { Rata- } \\
\text { rata }\end{array}$ \\
\hline 1. & $\begin{array}{l}\text { Sangat } \\
\text { Baik }\end{array}$ & $9-10$ & 22 & 210 & 66.67 & \multirow{5}{*}{$\begin{array}{l}293 / 33 \\
=8,88 \\
\text { berka } \\
\text { tegori } \\
\text { baik }\end{array}$} \\
\hline 2. & Baik & $7-8$ & 11 & 83 & 33.33 & \\
\hline 3. & Cukup & 4-6 & 0 & 0 & 0 & \\
\hline 4. & Kurang & $0-3$ & 0 & 0 & 0 & \\
\hline Jum & & & 33 & 293 & 100 & \\
\hline
\end{tabular}

Rata-rata kelas dalam penilaian menyimak dongeng pada aspek ini adalah 293/33=8,88. Dan termasuk dalam kategori baik.

Tabel 20. Hasil Tes Aspek Pilihan Kata Siklus I

\begin{tabular}{|c|c|c|c|c|c|c|}
\hline No & Kategori & $\begin{array}{l}\text { Rentang } \\
\text { Skor }\end{array}$ & Frekuensi & $\begin{array}{l}\text { Bobot } \\
\text { Skor }\end{array}$ & $\%$ & $\begin{array}{l}\text { Rata- } \\
\text { rata }\end{array}$ \\
\hline 1. & $\begin{array}{l}\text { Sangat } \\
\text { Baik }\end{array}$ & $9-10$ & 14 & 137 & 42.42 & $\begin{array}{l}288 / 3 \\
3=8,7\end{array}$ \\
\hline 2. & Baik & $7-8$ & 8 & 88 & 24.24 & $\begin{array}{l}\text { tegori } \\
\text { baik }\end{array}$ \\
\hline 3. & Cukup & $4-6$ & 11 & 63 & 33.33 & \\
\hline 4. & Kurang & $0-3$ & 0 & 0 & 0 & \\
\hline \multicolumn{3}{|c|}{ Jumlah } & 33 & 288 & 100 & \\
\hline
\end{tabular}

Rata-rata kelas dalam penilaian aspek ini adalah $288 / 33=8,7$ dan termasuk dalam kategori baik.

Tabel 21. Hasil Tes Aspek Penyusunan Kalimat Siklus I

\begin{tabular}{|l|l|l|l|l|l|l|}
\hline No & $\begin{array}{l}\text { Katego } \\
\text { ri }\end{array}$ & $\begin{array}{l}\text { Rentang } \\
\text { Skor }\end{array}$ & Frekuensi & $\begin{array}{l}\text { Bobot } \\
\text { Skor }\end{array}$ & $\begin{array}{l}\text { Rata- } \\
\text { rata }\end{array}$ \\
\hline 1. & $\begin{array}{l}\text { Sangat } \\
\text { Baik }\end{array}$ & $9-10$ & 13 & 126 & $35 \%$ & $\begin{array}{l}293 / 3 \\
3=8,8 \\
9 \\
\text { berka } \\
\text { tegori } \\
\text { baik }\end{array}$ \\
\hline 2. & Baik & $7-8$ & 11 & 85 & $35 \%$ & \\
\hline 3. & Cukup & $4-6$ & 9 & 51 & $30 \%$ & \\
\cline { 1 - 4 } 4. & Kurang & $0-3$ & 0 & 0 & 0 & \\
\cline { 1 - 3 } & & 33 & 1 & 100 & \\
\hline
\end{tabular}

Rata-rata kelas dalam hasil tes menyimak dongeng pada aspek ini adalah 293/33=8,89 dan termasuk dalam kategori baik.

\subsubsection{Hasil Non Tes}

Kategori perilaku siswa yang positif adalah serius mengikuti pembelajaran menyimak dongeng, mengikuti proses dengar-cerita dengan baik, menyimak dengan penuh perhatian. Kategori perilaku positif tersebut sebagian besar siswa sudah melakukannya dengan baik yaitu sebanyak 24 siswa atau $70 \%$. Sedangkan siswa yang tidak melakukannya dengan baik dari 24 perilaku positif tersebut ada 9 siswa atau $28 \%$. Ada 24 siswa atau $72 \%$ siswa yang berani menceritakan isi dongeng di depan kelas. Hal itu dikarenakan siswa yang lain tidak mau dengan alasan takut dan tidak bisa menceritakan isi dongeng di depan kelas.

Tabel 23 Hasil Jurnal Siswa Siklus I

\begin{tabular}{|l|l|l|l|}
\hline No. & Pilihan Jawaban & Frekuensi & Persentase \\
\hline 1. & $\begin{array}{l}\text { a. } \text { Ya } \\
\text { b. Tidak }\end{array}$ & $\begin{array}{r}\text { a. } 28 \\
\text { b. } 2\end{array}$ & $85 \%$ \\
\hline 2. & a. Mudah & a. 8 & $15 \%$ \\
\hline & b. Tidak Mudah & b. 14 & $42 \%$ \\
\hline 3. & a. Ya & a. 21 & $64 \%$ \\
\hline & b. Tidak & b. 21 & $64 \%$ \\
\hline 4. & a. Senang & a. 25 & $75 \%$ \\
\hline & b. Tidak Senang & b. 8 & $25 \%$ \\
\hline
\end{tabular}


Volume 3 Nomor 1, Halaman 1-81, Januari--Juni 2018

RISTEKDIK | Jurnal Bimbingan dan Konseling

P-ISSN: 2527-4244, E-ISSN : 2541-206X

Menurut hasil jurnal yang ditulis oleh siswa dan terlihat pada tabel 23 maka umumnya semua siswa merasa tertarik dan senang terhadap pembelajaran keterampilan menyimak dongeng dengan pendekatan integratif melalui teknik dengar-cerita. Aspek-aspek jurnal yang diisi oleh siswa meliputi (1) tertarik dan tidaknya siswa terhadap pembelajaran keterampilan menyimak dongeng dengan pendekatan integratif melalui teknik dengar-cerita, (2) penjelasan guru tentang pendekatan integratif melalui teknik dengarcerita, (3) kesulitan siswa dan tidaknya siswa ketika melakukan pembelajaran keterampilan menyimak dongeng dengan pendekatan integratif melalui teknik dengar-cerita, (4) perasaan siswa setelah melakukan pembelajaran keterampilan menyimak dongeng dengan pendekatan integratif melalui teknik dengar-cerita. Berikut uraian data hasil jurnal siswa pada siklus I.

\section{Wawancara}

Pertanyaan selanjutnya untuk siswa yang mendapatkan nilai tinggi, menjawab pertanyaan tentang penjelasan guru mengenai proses integratif mudah dipahami pada pembelajaran menyimak dongeng dengan teknik dengar-cerita. Siswa yang mendapat nilai sedang secara keseluruhan dapat mengikuti pembelajaran menyimak dongeng dengan baik. Siswa yang mendapat nilai rendah secara keseluruhan dapat mengikuti pembelajaran menyimak dengan baik, meskipun ada beberapa siswa yang kurang baik saat pembelajaran menyimak dongeng berlangsung.

\subsubsection{Hasil Siklus II}

Tabel 24. Skor Komulatif Menyimak Dongeng Siklus II

\begin{tabular}{|c|l|l|l|l|l|l|}
\hline No & Kategori & $\begin{array}{l}\text { Rentang } \\
\text { Skor }\end{array}$ & Frekuensi & $\begin{array}{l}\text { Bobot } \\
\text { Skor }\end{array}$ & $\%$ & Rata-rata \\
\hline 1. & Sangat Baik & $68-80$ & 11 & 863 & 33.33 & $\begin{array}{l}2182 / 33 \\
=66,12 \\
\text { berkate } \\
\text { gori } \\
\text { baik }\end{array}$ \\
\hline 2. & Baik & $56-67$ & 16 & 998 & 48.48 & \\
\hline 3. & Cukup & $44-55$ & 6 & 321 & 18.18 & \\
\hline 4. & Kurang & $0-43$ & 0 & 0 & 0 & \\
\cline { 1 - 3 } & & 33 & 2182 & 100 & \\
\hline
\end{tabular}

Rata-rata skor komulatif yaitu 2182:33=66,12. Hal tersebut menunjukkan bahwa pada skor komulatif menyimak dongeng secara klasikal berkategori baik.

Tabel 25. Nilai Komulatif Menyimak Dongeng Siklus II

\begin{tabular}{|c|c|c|c|c|c|c|}
\hline No & $\begin{array}{l}\text { Katego } \\
\text { ri }\end{array}$ & $\begin{array}{l}\text { Rentang } \\
\text { Nilai }\end{array}$ & Frekuensi & $\begin{array}{l}\text { Bobot } \\
\text { Nilai }\end{array}$ & $\%$ & $\begin{array}{l}\text { Rata- } \\
\text { rata }\end{array}$ \\
\hline 1. & $\begin{array}{l}\text { Sangat } \\
\text { Baik }\end{array}$ & $85-100$ & 15 & 1420 & 45.45 & \multirow{5}{*}{$\begin{array}{l}2782 / 3 \\
3=84,3 \\
\text { berkate } \\
\text { gori } \\
\text { baik }\end{array}$} \\
\hline 2. & Baik & $70-84$ & 13 & 1030 & 39.39 & \\
\hline 3. & Cukup & $55-69$ & 5 & 332 & 15.15 & \\
\hline 4. & Kurang & $0-54$ & 0 & 0 & 0 & \\
\hline \multicolumn{3}{|c|}{ Jumlah } & 33 & 2782 & 100 & \\
\hline
\end{tabular}

Rata-rata skor komulatif yaitu 2782:33=84,3

Tabel 26. Hasil Tes Aspek Kesesuaian Isi Dongeng Siklus II

\begin{tabular}{|c|l|l|l|l|l|l|}
\hline No & Kategori & $\begin{array}{l}\text { Rentang } \\
\text { Skor }\end{array}$ & Frekuensi & $\begin{array}{l}\text { Bobot } \\
\text { Skor }\end{array}$ & $\begin{array}{l}\text { Rata } \\
\text {-rata }\end{array}$ \\
\hline 1. & $\begin{array}{l}\text { Sangat } \\
\text { Baik }\end{array}$ & $16-20$ & 9 & 168 & 27.27 & $\begin{array}{l}460 / 33 \\
=13,94 \\
\text { berkate } \\
\text { gori } \\
\text { baik }\end{array}$ \\
\hline 2. & Baik & $11-15$ & 16 & 220 & 48.48 & \\
\cline { 1 - 5 } 3. & Cukup & $6-10$ & 8 & 72 & 24.24 & \\
\cline { 1 - 4 } 4. & Kurang & $0-5$ & 0 & 0 & 0 & \\
\cline { 1 - 3 } Jumlah & & 33 & 460 & 100 & \\
\hline
\end{tabular}

Nilai rata-rata kelas pada aspek ini adalah $460 / 33=13,94$ dan termasuk dalam kategori baik.

Tabel 27. Hasil Tes Aspek Tokoh dan

Perwatakan Siklus II

\begin{tabular}{|c|c|c|c|c|c|c|}
\hline No & $\begin{array}{l}\text { Katego } \\
\text { ri }\end{array}$ & $\begin{array}{l}\text { Rentang } \\
\text { Skor }\end{array}$ & Frekuensi & $\begin{array}{l}\text { Bobot } \\
\text { Skor }\end{array}$ & $\%$ & Rata-rata \\
\hline 1. & $\begin{array}{l}\text { Sangat } \\
\text { Baik }\end{array}$ & $16-20$ & 14 & 256 & 42.42 & \multirow{5}{*}{$\begin{array}{l}489 / 33 \\
=14,82 \\
\text { berkate } \\
\text { gori } \\
\text { baik }\end{array}$} \\
\hline 2. & Baik & $11-15$ & 13 & 179 & 39.39 & \\
\hline 3. & Cukup & $6-10$ & 6 & 54 & 18.18 & \\
\hline 4. & Kurang & $0-5$ & & 0 & 0 & \\
\hline Jum & & & 33 & 489 & 100 & \\
\hline
\end{tabular}


Volume 3 Nomor 1, Halaman 1-81, Januari--Juni 2018

RISTEKDIK | Jurnal Bimbingan dan Konseling

P-ISSN: 2527-4244, E-ISSN : 2541-206X

6

\begin{tabular}{|l|l|l|l|l|l|r|}
\hline No & Kategori & $\begin{array}{l}\text { Rentan } \\
\text { g } \\
\text { Skor }\end{array}$ & Frekuensi & $\begin{array}{l}\text { Bobot } \\
\text { Skor }\end{array}$ & $\%$ & $\begin{array}{r}\text { Rata } \\
\text {-rata }\end{array}$ \\
\hline 1. & Sangat Baik & $9-10$ & 23 & 220 & 69.70 & $\begin{array}{r}294 / 3 \\
3=8,9 \\
\text { berka } \\
\text { tegori } \\
\text { baik }\end{array}$ \\
\hline 2. & Baik & $7-8$ & 10 & 74 & 30.30 & \\
\hline 3. & Cukup & $4-6$ & 0 & 0 & 0 & \\
\cline { 1 - 3 } 4. & Kurang & $0-3$ & 0 & 0 & 0 & \\
\cline { 1 - 2 } Jumlah & & 33 & 294 & 100 & \\
\hline
\end{tabular}

Rata-rata kelas dalam penilaian menyimak dongeng pada aspek ini adalah 319/33=9,7.

Dan termasuk dalam kategori sangat baik.

Tabel 30. Hasil Tes Aspek Pilihan Kata

Siklus II

Rata-rata kelas dalam penilaian aspek ini adalah 294/33=8,9 dan termasuk dalam kategori baik.

Tabel 31. Hasil Tes Aspek Penyusunan Kalimat Siklus II

Nilai rata-rata kelas dalam aspek ini adalah $489 / 33=14,82$ dan termasuk dalam kategori baik.

Tabel 28. Hasil Tes Aspek Latar Siklus II

\begin{tabular}{|l|l|l|l|l|l|l|}
\hline No & Kategori & $\begin{array}{l}\text { Rentang } \\
\text { Skor }\end{array}$ & Frekuensi & $\begin{array}{l}\text { Bobot } \\
\text { Skor }\end{array}$ & $\begin{array}{l}\text { Rata } \\
\text {-rata }\end{array}$ \\
\hline 1. & $\begin{array}{l}\text { Sangat } \\
\text { Baik }\end{array}$ & $9-10$ & 17 & 166 & 51.52 & $\begin{array}{l}278 / 33 \\
=8,4 \\
\text { berkate } \\
\text { gori } \\
\text { baik }\end{array}$ \\
\hline 2. & Baik & $7-8$ & 11 & 85 & 33.33 & \\
\hline 3. & Cukup & $4-6$ & 5 & 27 & 15.15 & \\
\cline { 1 - 4 } 4. & Kurang & $0-3$ & 0 & 0 & 0 & \\
\hline \multicolumn{2}{|l|}{ Jumlah } & & 33 & 278 & 100 & \\
\hline
\end{tabular}

\begin{tabular}{|c|c|c|c|c|c|c|}
\hline No & Kategori & \begin{tabular}{|l} 
Rentan \\
g \\
Skor
\end{tabular} & Frekuensi & $\begin{array}{l}\text { Bobot } \\
\text { Skor }\end{array}$ & $\%$ & Rata-rata \\
\hline 1. & Sangat Baik & $9-10$ & 17 & 167 & 51.52 & \multirow{5}{*}{$\begin{array}{l}280 / 33 \\
=8,5 \\
\text { berkate } \\
\text { gori } \\
\text { baik }\end{array}$} \\
\hline 2. & Baik & $7-8$ & 13 & 97 & 39.39 & \\
\hline 3. & Cukup & $4-6$ & 3 & 16 & 9.09 & \\
\hline 4. & Kurang & $0-3$ & 0 & 0 & 0 & \\
\hline \multicolumn{2}{|c|}{ Jumlah } & & 33 & 280 & 100 & \\
\hline
\end{tabular}

Rata-rata kelas dalam hasil tes menyimak 4.1.6. Hasil Nontes Siklus II dongeng aspek latar adalah sebesar 278/33=8,4 dan termasuk dalam kategori baik.

Dari data observasi tersebut pada siklus II maka siswa yang mempunyai perilaku positif lebih banyak dibanding siswa yang mlakukan

Tabel 29. Hasil Tes Aspek Mimik Siklus II

\begin{tabular}{|l|l|l|l|l|l|l|}
\hline No & Kategori & $\begin{array}{l}\text { Rentan } \\
\text { Skr } \\
\text { Skor }\end{array}$ & Frekuensi & $\begin{array}{l}\text { Bobot } \\
\text { Skor }\end{array}$ & $\%$ & Rata-rata \\
\hline 1. & Sangat Baik & $9-10$ & 19 & 184 & 57.58 & $\begin{array}{l}319 / 33=9 \\
, 7 \\
\text { berkatego } \\
\text { risangat } \\
\text { baik }\end{array}$ \\
\hline 2. & Baik & $7-8$ & 14 & 108 & 42.42 & \\
\hline 3. & Cukup & $4-6$ & 0 & 0 & 0 & \\
\hline 4. & Kurang & $0-3$ & 0 & 0 & 0 & \\
\hline \multicolumn{1}{|l|}{ Jumlah } & & 33 & 319 & 100 & \\
\hline
\end{tabular}
kegiatan negative selama pembelajaran menyimak dongeng berlangsung. Hal ini berarti siswa lebih perhatian terhadap pemberlajaran menyimak dongeng dengan teknik dengar-cerita melalui pendekatan integratif pada siklus II. 
Tabel 33 Hasil Jurnal Siswa Siklus II

\begin{tabular}{|l|l|l|l|}
\hline No. & $\begin{array}{l}\text { Pilihan } \\
\text { Jawaban }\end{array}$ & Frekuensi & Persentase \\
\hline 1. & $\begin{array}{l}\text { a. Ya } \\
\text { b. Tidak }\end{array}$ & a. 30 & a. $90 \%$ \\
\hline 2. & $\begin{array}{l}\text { a. Mudah } \\
\text { b. Tidak Mudah }\end{array}$ & $\begin{array}{l}\text { a. } 30 \\
\text { b. } 3\end{array}$ & a. $90 \%$ \\
b. $10 \%$
\end{tabular}

Berdasarkan hasil wawancara pada siklus II, diketahui bahwa kedua siswa tersebut saat diwawancara mengenai apakah siswa senang dan tertarik terhadap pembelajaran menyimak dongeng dengan pendekatan integratif melalui teknik dengar-cerita, kedua siswa tersebut menjawab tertarik dan senang mengikuti pembelajaran menyimak dongeng dengan pendekatan integratif melalui teknik dengarcerita.

Untuk pertanyaan selanjutnya maka siswa yang mendapatkan nilai tinggi, menjawab pertanyaan mengenai penjelasan guru mengenai proses integratif mudah dipahami pada pembelajaran menyimak dongeng dengan teknik dengar-cerita. Siswa yang mendapat nilai sedang secara keseluruhan dapat mengikuti pembelajaran menyimak dongeng dengan baik. Siswa yang mendapat nilai rendah dapat mengikuti pembelajaran menyimak dengan baik, akan tetapi ada beberapa siswa yang kurang baik saat pembelajaran menyimak dongeng berlangsung.

\section{PEMBAHASAN}

Penelitian yang dilakukan merupakan penelitian tindakan kelas yang terdiri dua siklus yaitu siklus I dan siklus II. Setiap siklus melalui beberapa tahap, yaitu perencanaan, tindakan, pengamatan (observasi), dan refleksi. Pada siklus II, tahaptahap tersebut dilaksanakan dengan perbaikan dari pembelajaran siklus I.

Hasil penelitian ini diperoleh dari data tes dan nontes, baik pada siklus I maupun sikls II.
Hasil pada kedua siklus tersebut digunakan untuk mengetahui peningkatan keterampilan siswa dalam menyimak dongeng teknik dengar-cerita melalui pendekatan integratif. Selain itu, untuk mengetahui perubahan perilaku siswa selama mengikuti proses pembelajaran. Berikut ini uraian pelaksanaan perolehan data pada pratindakan, siklus I, dan siklus II.

Nilai rata-rata yang diperoleh pada pratindakan yaitu 67,10. Berdasarkan pengamatan diketahui bahwa siswa kurang berminat dalam belajar karena materi simakan dibacakan oleh guru, sehingga proses pembelajaran berjalan membosankan. Dan siswa banyak yang berperilaku negatif.

Berdasarkan hasil tes dan jurnal pada siklus I, peneliti dapat mengetahui kelemahankelemahan yang dialami siswa selama proses pembelajaran berlangsung.

Peningkatan keterampilan menyimak dongeng dari pratindakan ke siklus II. Pada nilai indikator mengalami peningkatan sebesar 18,3 poin. Dan untuk aspek menyusun kalimat mengalami peningkatan sebesar 2,1 poin. Sedangkan untuk skor komulatif pada aspekaspek menyimak dongeng mengalami peningkatan sebesar 4,4 poin.

Pada aspek mimik mengalami peningkatan. Hal ini disebabkan karena keseriusan siswa. Untuk nilai rata-rata pada skor total pada enam aspek menyimak dongeng maka pada setiap siklusnya juga mengalami peningkatan. Hal ini disebabkan pada setiap aspek yang telah dijelaskan di atas telah mengalami peningkatan sehingga secara otomatis untuk nilai rata-rata pada skor total pada keenam aspek menyimak dongeng juga mengalami peningkatan.

Dengan adanya peningkatan skor ratarata tiap siklusnya membuktikan bahwa pembelajaran menyimak dongeng dengan pendekatan integratif melalui teknik dengarcerita dapat menjadikan siswa tertarik terhadap pembelajaran menyimak khususnya menyimak dongeng dan memotivasi siswa dalam pembelajaran menyimak.

Berdasarkan hasil nontes yaitu melalui observasi, jurnal, wawancara maka dapat 
disimpulkan bahwa kesiapan siswa mengikuti pembelajaran menyimak dongeng kurang maksimal dan belum begitu memuaskan meskipun siswa terlihat antusias terhadap materi yang disampaikan guru. Dari hasil observasi siklus I masih ditemukan beberapa tingkah laku yang negative dalam mengikuti pembelajaran.

Secara umum pelaksanaan pembelajaran menyimak dongeng pada siklus I dan siklus II berlangsung dengan baik dan lancar. Dilihat dari perubahan perilaku siswa ketika pembelajaran menyimak dongeng dengan teknik dengar-cerita melalui pendekatan integratif. Guru harus bisa memilih pendekatan yang sesuai pada setiap proses pembelajaran. Hal itu diharapkan agar hasil yang dicapai siswa bisa maksimal. Menurut Suyatno (2004:26), integratif berarti menyatukan beberapa aspek ke dalam satu proses. Dari pendapat tersebut maka pembelajaran melalui proses integratif menuntut siswa untuk aktif dalam pembelajaran yaitu menguasai empat keterampilan berbahasa. Dengan demikian, melalui proses integratif dalam pembelajaran menyimak dongeng telah terjadi perubahan perilaku yang dialami oleh siswa yaitu siswa yang mulanya tidak mengerti makna pembelajaran. Setelah proses pembelajaran siswa jadi paham akan makna dan konsep pengetahuan yang bermanfaat bagi mereka. Nilai hasil belajar siswa juga telah mengalami peningkatan sesuai dengan target yang telah ditetapkan. Oleh karena itu, penelitian ini telah berhasil dan tidak perlu untuk dilanjutkan pada siklus berikutnya.

\section{KESIMPULAN} Berdasarkan hasil penelitian dan
pembahasan, peneliti menyimpulkan sebagai berikut.

1. Keterampilan menyimak dongeng pada siswa kelas II SD Negeri 200106 Padangsidimpuan mengalami peningkatan, setelah mengikuti pembelajaran menyimak dongeng dengan pendekatan integratif melalui teknik dengar-cerita Hasil rata-rata tes menyimak dongeng pratindakan sebesar 67,10 , dan pada siklus I rata-rata nilainya menjadi 70 dan meningkat sebesar 2,9\% dari pratindakan, kemudian pada siklus II diperoleh rata-rata sebesar 84,3 atau meningkat sebesar $14,3 \%$ dari rata-rata siklus I. Perolehan hasil ini menunjukkan bahwa pembelajaran menyimak dongeng dengan pendekatan integratif melalui teknik dengar-cerita pada siswa kelas II SD Negeri 200106 Padangsidimpuan dapat berhasil.

2. Perilaku siswa kelas II SD Negeri 200106 Padangsidimpuan setelah mengikuti pembelajaran menyimak dongeng dengan pendekatan integratif melalui teknik dengarcerita mengalami perubahan ke arah positif. Perubahan tersebut yaitu siswa kelihatan lebih antusias dan senang saat pembelajaran menyimak dongeng dengan pendekatan integratif melalui teknik dengar-cerita.

\section{DAFTAR PUSTAKA}

Alwi, Hasan. 2002. Kamus Besar Bahasa Indonesia. Jakarta: Balai Pustaka.

Danandjaja, James. 1991. Folkor Indonesia. Jakarta: PT.Temprint.

Djiwandono, S. 1996. Tes Bahasa dan Pengajaran. Bandung: ITB

Mulyasa. 2004. Kurikulum Berbasis Kompetensi: Konsep, Karakteristik, dan Implementasinya. Bandung: PT Rosdakarya.

Nurgiyantoro, Burhan. 2001. Penilaian Dalam Pengajaran Bahasa Dan Sastra. Yogyakarta: PT BPFE.

Nurhadi. 2004. Kurikulum 2004. Jakarta: PT Gramedia Widiasarana.

Nursisto. 2000. Ikhtisar Kesusatraan Indonesia. Yogyakarta: Adicita.

Sudjana, Nana. 2005. Penilaian Hasil Proses Belajar Mengajar. Bandung: PT Remaja Rosdakarya.

Surana. 2004. Aku Cinta Bahasa Indonesia. Solo: PT Tiga Serangkai Pustaka Mandiri.

Sutari, dkk. 1997. Menyimak. Jakarta: Depdikbud.

Suyatno. 2004. Teknik Pembelajaran Bahasa dan Sastra. Surabaya: SIC.

Tarigan, Djago. 1991. Materi pokok Pendidikan Bahasa Indonesia I. Jakarta: Depdikbud.

Tarigan, Henry Guntur. 1993. Menyimak Sebagai Suatu Keterampilan Berbahasa. Bandung: Angkasa.

Zainuddin. 1991. Materi Pokok Bahasa dan Sastra Indonesia. Jakarta: Rineka Cipta. 